\title{
PHARMACOTHERAPEUTICAL APPROACHES TO DECREASING HEMATOCRIT AND INCREASING CLAUDICATION DISTANCE IN DIABETIC PATIENTS WITH PERIPHERAL VASCULAR DISEASE
}

\author{
Ján Ürge ${ }^{\mathrm{a}}$ Jan Strojil ${ }^{\mathrm{b}}$, Petr Utíkal ${ }^{\mathrm{c}}$ \\ a $2^{\text {nd }}$ Internal Clinic, Teaching Hospital, Palacký University, I. P. Pavlova 6, 77520 Olomouc, Czech Republic \\ ${ }^{b}$ Department of Pharmacology, Teaching Hospital, Palacký University \\ c $2^{\text {nd }}$ Department of Surgery, Teaching Hospital, Palacký University
}

Received: May 2, 2005; Accepted (with revisions): November 25, 2005

Key words: Diabetes mellitus/Peripheral vascular disease/Haemodilution/Hydroxyethyl starch/Claudication distance/ Conservative treatment

The paper deals with pharmacotherapeutical approaches to decreasing hematocrit in order to improve macro and microcirculation in arteries of lower limbs of type 2 diabetes patients. The study included 37 patients with diabetic angiopathy, all of whom had inoperable changes to arteries. In order to decrease hematocrit and cause haemodilution, we used $10 \%$ solution of hydroxyethyl starch. Indications for inclusion in the study were carried out in close cooperation with a vascular surgeon. We applied hydroxyethyl starch according to a predetermined scheme. Using normovolemic and hypervolemic haemodilution, we decreased hematocrit to $0.41-0.42$. Patients underwent a treadmill examination at the beginning of the study and then repeatedly during the course of study, when we measured the claudication distance to quantify, the effects of decreased hematocrit.

The results show that the effect is most pronounced after 6 weeks, when hematocrit fell from a baseline of 0.435 to 0.421 ( $\mathrm{p}<0.01$ ) and claudication distance increased to $51 \%$ (also significant). On average the claudication distance rose from $55.7 \mathrm{~m}$ to $84.6 \mathrm{~m}(\mathrm{p}<0.01)$. In the following weeks (after the sixth week of the study), the studied parameters changed only insignificantly $(\mathrm{p}>0.05)$.

\section{INTRODUCTION}

The coincidence of type 2 diabetes and peripheral vascular disease (PVD) is very common and constitutes the most common cause of diabetic angiopathy. The incidence of PVD in type 2 diabetic patients is around $30 \%$. According to some studies, the risk of ischemic limb disease manifesting itself is 5 times higher for diabetic patients than it is for non-diabetics. The probability of ischemic gangrene of lower limb is $20-30$ times higher for diabetics ${ }^{1,2}$.

An important pathophysiological mechanism in the development of diabetic angiopathy, apart from classical risk factors of atherosclerosis, is blood fluidity and loss of autoregulation of vascular tone. With already existing angiopathy, blood fluidity becomes the limiting factor for blood flow to poorly perfused areas ${ }^{3}$.

One of the options of influencing blood viscosity by decreasing hematocrit is haemodilution by hydroxyethyl starch (HES) application.

Treatment by HES leads to improved rheological properties of blood and to improvement in macro and microcirculation by normo or hypervolemic haemodilution. This leads to increased oxygen supply to the tissues and restoration of disturbed metabolism ${ }^{4-7}$.

Decrease in hematocrit is in fact linked to a corresponding decrease in concentration of oxygen carriers and so decreases the oxygen carrying capacity of blood. This loss if compensated for by a decrease in blood viscosity, supercompensates the loss of total oxygen concentration in blood by increasing its relative transport capacity.

According to a simplified modification of the HagenPoiseulle equation is tissue perfusion indirectly proportional to blood viscosity and directly proportional to perfusion pressure.

\section{METHODS AND MATERIAL}

The studied population consisted of 37 patients with diabetic angiopathy, stages II-IV of the Fontaine classification, treated by haemodilution at the $2^{\text {nd }}$ Internal Clinic of Teaching Hospital in Olomouc, from 1998 to 2003. We used a $10 \%$ solution of hydroxyethyl starch from the company Fresenius (Haes-steril 10\%).

\section{Solution characteristics}

Hydroxyethyl starch is a solution with a molecular weight of $200 \mathrm{kDa}$ and molar substitution 0.5 (i.e. approx. 5 hydroxyethyl groups are present in 10 glucose units of the amylopectin skeleton). It is of vegetable origin, made from maize. $96 \%$ of HES is in the form of high molecular weight amylopectin, the structure of which is similar to glycogen. It is excreted largely through kidneys, part of the 
dose administered penetrates into extravascular compartment and is excreted in bile and stool ${ }^{8}$.

Inclusion criteria of patients indicated for haemodilution treatment with HES:

- inoperable diabetic angiopathy of lower limbs

- patients after an unsuccessful revascularisation operation

As unsuccessful revascularisation we consider (further just unsuccessful intervention):

- technical failure of the procedure without restoring the blood flow through the vessel

- bypass or angioplasty obliteration

- functional failure of intervention, when there is neither subjective nor objective improvement in clinical condition (change in ankle-brachial index) despite a technically successful operation

Another criterion for initiation of haemodilution treatment was hematocrit higher than 0.42 and no contraindication for HES treatment ${ }^{9}$.

We measured hematocrit levels at inclusion and then repeated the measurements

- once a week during the first six weeks

- once a month in the follow up period

\section{Claudication distance}

To determine the claudication intervals we followed a pre set scheme, using treadmill Jaeger LE 3000 with the option to change the slope and speed. The standard speed was $3 \mathrm{~km} / \mathrm{h}$ with $12 \%$ slope, time of exercise 5 min. $^{10}$

The measurement was done before treatment initiation and then in specified intervals during the study.

We recorded the following data:

Distance in meters walked

a) until onset of pain
a. walking horizontally, speed $3 \mathrm{~km} / \mathrm{h}$
b. walking horizontally, speed $5 \mathrm{~km} / \mathrm{h}$
c. walking up a slope of $12 \%$, speed $3 \mathrm{~km} / \mathrm{h}$

b) until pain limited further exercise
a. walking horizontally, speed $3 \mathrm{~km} / \mathrm{h}$
b. walking horizontally, speed $5 \mathrm{~km} / \mathrm{h}$
c. walking up a slope of $12 \%$, speed $3 \mathrm{~km} / \mathrm{h}$

Patient treatment consisted of hydroxyethyl starch (HES) parenteral application, $250 \mathrm{ml}$ in a sixty minute i.v. infusion. We included a total of 37 patients, follow up period ranged from 12 months to 3 years. None of the patients included had hematocrit values higher than 0.45 .

The following table shows the characteristics of the studied sample.

Table 1. Patients by sex and age.

\begin{tabular}{|l|c|c|c|}
\hline & Average age & Maximum & Minimum \\
\hline Male & 60.37 & 75 & 42 \\
\hline Female & 60.68 & 72 & 49 \\
\hline Total & 60.52 & 75 & 42 \\
\hline
\end{tabular}

Table 2. Patients by disease stage according to Fontain classification.

\begin{tabular}{|l|c|c|c|}
\hline & Total & Male & Female \\
\hline Fontain IIa & 7 & 4 & 3 \\
\hline Fontain IIb & 17 & 12 & 5 \\
\hline Fontain III & 10 & 7 & 3 \\
\hline Fontain IV & 3 & 3 & 0 \\
\hline
\end{tabular}

Table 3. Concomitant disease and their frequency.

\begin{tabular}{|l|c|c|}
\hline Ischemic heart disease & 34 & $81 \%$ \\
\hline Arterial hypertension & 29 & $69 \%$ \\
\hline Obesity & 36 & $86 \%$ \\
\hline Hyperlipoproteinaemia & 39 & $93 \%$ \\
\hline Renal failure & 3 & $9 \%$ \\
\hline Microalbuminuria & 38 & $90 \%$ \\
\hline
\end{tabular}

Table 4. Treatment duration.

\begin{tabular}{|l|c|c|}
\hline \multirow{2}{*}{$\begin{array}{l}\text { Treatment } \\
\text { duration }\end{array}$} & Fontain IIb & Fontain III-IV \\
\cline { 2 - 3 } $\begin{array}{l}\text { week 1-3 } \\
\text { (inpat./outpat.) }\end{array}$ & $\begin{array}{l}\text { 3 times } \\
\text { a week }\end{array}$ & 5 times a week \\
\hline $\begin{array}{l}\text { week 4-6 } \\
\text { (outpatient) }\end{array}$ & 1 time a week & 3 times a week \\
\hline
\end{tabular}

After six weeks and after six months we evaluated the clinical effect of treatment. We recorded subjective feelings of the patients, measured hematocrit, measured peripheral pressure indexes and claudication distances. We used Student's t-test to evaluate the results.

\section{RESULTS}

Hematocrit decreased from average 0.435 baseline value to 0.421 after six weeks of treatment, this change was statistically significant $(\mathrm{p}<0.01)$. There was difference in the decrease of hematocrit in relation to the frequency of infusions. During follow up after the first six weeks of treatment there were no further significant decreases in hematocrit, some measurements even showed a non significant increase.

None of the changes seen during the follow up period were significant. Fluctuation of hematocrit levels agrees with the hypothesis that the influence on rheological properties of blood is greatest when HES is applied weekly. However, the assumption that the effect would last for 
Table 5. Average values of hematocrit before and during treatment (s.d. - standard deviation)

\begin{tabular}{|c|c|c|c|c|c|}
\hline \multirow{2}{*}{$\begin{array}{c}\text { Before } \\
\text { treatment }\end{array}$} & \multicolumn{4}{|c|}{ During treatment (weeks) } \\
\cline { 3 - 6 } & & 6 & 24 & 52 & 104 \\
\hline \multirow{2}{*}{ Hematocrit } & 0.435 & 0.425 & 0.421 & 0.432 & 0.440 \\
& s.d. 0.110 & s.d. 0.155 & s.d. 0.174 & s.d. 0.185 & s.d. 0.192 \\
\hline
\end{tabular}

Table 6. Average claudication distances in meter measured by walking on the treadmill before and during treatment.

\begin{tabular}{|c|c|c|c|c|c|}
\hline & \multirow{2}{*}{$\begin{array}{l}\text { Before } \\
\text { treatment }\end{array}$} & \multicolumn{4}{|c|}{ During treatment (weeks) } \\
\hline & & 6 & 24 & 52 & 104 \\
\hline $\begin{array}{l}\text { Claudication distance } \\
(\mathrm{v}=3 \mathrm{~km} / \mathrm{h} \text {, slope } 0 \%)\end{array}$ & $\begin{array}{c}55.7 \\
\text { s.d. } 26.3\end{array}$ & $\begin{array}{c}\quad 84.58 \\
\text { s.d. } 38.24\end{array}$ & $\begin{array}{c}86.64 \\
\text { s.d. } 38.86\end{array}$ & $\begin{array}{c}89.51 \\
\text { s.d. } 32.89\end{array}$ & $\begin{array}{c}89.2 \\
\text { s.d. } 34.5\end{array}$ \\
\hline $\begin{array}{l}\text { Claudication distance } \\
(\mathrm{v}=5 \mathrm{~km} / \mathrm{h} \text {, slope } 0 \%)\end{array}$ & $\begin{array}{c}26.02 \\
\text { s.d. } 23.29\end{array}$ & $\begin{array}{c}26.41 \\
\text { s.d. } 23.75\end{array}$ & $\begin{array}{c}25.36 \\
\text { s.d. } 24.11\end{array}$ & $\begin{array}{c}24.74 \\
\text { s.d. } 24.62\end{array}$ & $\begin{array}{c}24.63 \\
\text { s.d. } 21.89\end{array}$ \\
\hline
\end{tabular}

14-21 days was not confirmed, in some of the measurements hematocrit was increased.

Increase in claudication distances correlated with hematocrit decrease. On average the claudication interval significantly increased by $51 \%$ from baseline of $55.7 \mathrm{~m}$ to $84.6 \mathrm{~m}(\mathrm{p}<0.01)$, measured after six weeks of treatment.

In the follow up period, the claudication distances changed only little, with values of $p$ around 0.05 . It is possible that some of the increase in claudication distance could be attributed to patients becoming more adapted to walking on the treadmill with repeated examinations, since none of the patients had used the treadmill before being included in this study.

\section{DISCUSSION}

When considering application of hydroxyethyl starch in order to decrease hematocrit, cause haemodilution and so improve the ischemia present in diabetic angiopathy, we assumed the following generally known and accepted facts:

- diabetic patients are more prone to unfavourable rheological changes ${ }^{11}$

- coincidence of classical risk factors for atherosclerosis (which is the morphological bases of macroangiopathy) and blood fluidity ${ }^{2,3}$.

In theory, haemodilution by application of hydroxyethyl starch should be effective since in diabetic angiopathy, damage to arteries predominates and blood fluidity becomes a limiting factor for proper tissue oxygenation.

The principle of hydroxyethyl starch treatment is achieving normovolemic or hypervolemic haemodilution.

This haemodilution accompanied by hematocrit decrease to values between 0.40 and 0.42 is beneficial, improves rheological properties of blood and supports more efficient tissue oxygenation. It has been shown that hematocrit between 0.40 and 0.42 is ideal for oxygen transport ${ }^{4}$.

To reach the target values, we repeatedly applied infusions of $10 \%$ hydroxyethyl starch, each $500 \mathrm{ml}$ in volume. This dosing is sufficient when hematocrit does not exceed 0.45 .

Haemodilution treatment using HES is most effective in the first 6 weeks, which was confirmed by statistically significant decrease in values of hematocrit and claudication distance.

Five patients did not complete the study. Four of them had to be excluded from the study for serious deterioration in their clinical condition. One moved and could not continue the study.

One patient left the study after an ischemic stroke. The complication was not associated with HES treatment. In contrast, HES is used in the treatment of ischemic strokes.

Two patients showed progression of peripheral vascular damage with the appearance of resting pain and trophic defects. These two patients were transfered to the surgery department and had their feet amputated above ankle level.

One patient died of lung cancer. The diagnosis of the tumour was preceded by obliteration of femoropopliteal bypass with high amputation of the lower limb involved. The hypercoagulation state was so marked that it could not be sufficiently treated by haemodilution, on other conservative means (intraarterial trombolysis).

\section{CONCLUSIONS}

After evaluation of our results, we came to the conclusion that controlled decrease of hematocrit favourably af- 
fects the symptoms of diabetic angiopathy. Haemodilution as a treatment option is:

(i) simple and effective;

(ii) most effective in diabetic patients with inoperable changes in lower limb arteries;

(iii) possible to administer to outpatients, without the need for hospitalisation;

(iv) well tolerated and safe.

We therefore conclude that the prospects of using hydroxyethyl starch for haemodilution treatment are very favourable.

\section{REFERENCES}

1. Válek J. Diabetická makroangiopatie. In: Bartoš V, Pelikánová T. Praktická diabetologie. Maxdorf Praha, 2003. p. 206-213.

2. Angelkort B, Kiesewetter H. (1981) Influence of risk factors and coagulation phenomena on the fluidity of blood in chronic arterial occlusive disease. Scand J Clin Lab Invest 41, 185-188.
3. Angelkort B, Pirnay D, Kiesewetter H, Maurin N. (1983) Hemodilution and pentoxifyllin effects on muscle blood flow and blood fluidity in chronic arterial occlusive disease. Vascular Med 1, 150158.

4. Koscielny J, Kiesewetter H, Jung E. Hemodilution, Springer-Verlag Berlin Heidelberg, 1992.

5. Stacher A. (1984) Klinik und Therapie des Eisenmangels. Wiener Med Wochenschr 1, 76.

6. Heidrich H, Boccalon H (1986) Prinzipien kontrollierter klinischer Therapiestudien bei peripherer arterieller Verschlusskrankheit. Angio Archiv 13, 82.

7. Weidwager P, Bach N. 5 Jahre Wiener Erfehrungen mit ambulanten Claudicatio-Gruppen. In: Kiesewetter H, Jung F, editors. Konservative Therapie peripherer und zerebraler arterieller Durchblutungsstörungen, Ermer Verlag, 1987. p. 21-63.

8. Automatický informační systém léčivých přípravků (AISLP), 2004. 4.

9. Kiesewetter H, Junge F, Blume J, Gerhards M. (1987) Hämodilution bei Patienten mit periphere arterieller Verschlusskrankheit im Stadium II b: Prospektive randomisierter Doppelblind-Vergleich von mittelmolekularer Hydroxyäthylstärke und kleinmolekularerDextranlösung. Klin Wochenschr 65, 324-330.

10. Puchmayer V. (1977) Použití ultrazvukové techniky v angiologii. Vnitř. Lék. 23, 1072-1082.

11. Carr ME. (2001) Diabetes mellitus: a hypercoagulable state. J Diabetes Complications 15, 44-54. 